University of Nebraska - Lincoln

DigitalCommons@University of Nebraska - Lincoln

Roman L. Hruska U.S. Meat Animal Research

U.S. Department of Agriculture: Agricultural Center

Research Service, Lincoln, Nebraska

2005

\title{
Allelic Variation in the Erythropoietin Receptor Gene is Associated with Uterine Capacity and Litter Size in Swine
}

J. L. Vallet

USDA-ARS, vallet@email.marc.usda.gov

B. A. Freaking

USDA-ARS

K. A. Leymaster

USDA-ARS

R. K. Christenson

USDA-ARS

Follow this and additional works at: https://digitalcommons.unl.edu/hruskareports

Vallet, J. L.; Freaking, B. A.; Leymaster, K. A.; and Christenson, R. K., "Allelic Variation in the Erythropoietin Receptor Gene is Associated with Uterine Capacity and Litter Size in Swine" (2005). Roman L. Hruska U.S. Meat Animal Research Center. 254.

https://digitalcommons.unl.edu/hruskareports/254

This Article is brought to you for free and open access by the U.S. Department of Agriculture: Agricultural Research Service, Lincoln, Nebraska at DigitalCommons@University of Nebraska - Lincoln. It has been accepted for inclusion in Roman L. Hruska U.S. Meat Animal Research Center by an authorized administrator of DigitalCommons@University of Nebraska - Lincoln. 


\title{
Allelic variation in the erythropoietin receptor gene is associated with uterine capacity and litter size in swine*
}

\author{
J. L. Vallet, B. A. Freking, K. A. Leymaster and R. K. Christenson \\ USDA, ARS, Roman L. Hruska US Meat Animal Research Center, Clay Center, NE 68933, USA
}

\begin{abstract}
Summary
A single nucleotide polymorphism (SNP; $C$ vs. T) that creates an extra GATA-1 site ( $T$ allele) in intron 4 of the swine erythropoietin receptor (EPOR) gene was discovered and a genotyping assay for this SNP was developed. A total of 402 gilts from lines selected either at random (control), for ovulation rate (OR) or for uterine capacity (UC) for 11 generations were unilaterally hysterectomized-ovariectomized (UHO) at 160 days of age, mated at approximately 250 days of age and slaughtered at 105 days of pregnancy. Blood samples and spleens were collected from each foetus and the numbers of corpora lutea (CL) and live foetuses, the weights of each foetus and placenta, and each foetal haematocrit were recorded. In addition, intact gilts from the OR line or from a Yorkshire, Landrace, Duroc, crossbred line (BX) were mated and farrowed. At farrowing, the numbers of fully formed and live piglets were recorded for each litter. Genomic DNA was isolated for both the UHO and intact gilts, from foetuses from the UHO gilts that were heterozygous for the EPOR SNP, and from the boars from the BX line and were then used to determine EPOR SNP genotypes. Only CC and CT gilts were observed in the control, OR and UC selected lines. Presence of the EPOR $T$ allele was associated $(P<0.05)$ with increased UC in these gilts. The number of heterozygous and homozygous foetuses did not differ within UHO litters, or did EPOR genotype influence foetal haematocrit. In intact gilts from the OR line, litter size was significantly associated $(P<0.05)$ with EPOR SNP genotype. Finally, results from intact gilts of the BX line, in which both the gilt and the boar genotypes were known, allowed an analysis to determine the effect of the gilt and/or the foetal genotype on litter size. This analysis indicated that the predicted foetal genotype (with gilt genotype as covariate) was associated with litter size (an increase of $2.6 \pm 1.0$ piglets born alive predicted for homozygous $T$ litters compared with homozygous $C$ litters, $P<0.01$ ) whereas the effect of the gilt genotype (adjusted for foetal genotype) on litter size was not significant. These results indicate that the EPOR SNP is associated with UC and litter size in two distinct populations and could be useful in increasing litter size in swine that are not limited in OR.
\end{abstract}

Keywords erythropoiesis, foetus, placenta, pregnancy.

Address for correspondence

J. L. Vallet, USDA, ARS, RLH US Meat Animal Research Center, PO Box 166, State Spur 18D, Clay Center, NE 68933-0166, USA.

E-mail: vallet@email.marc.usda.gov

* Names are necessary to report factually on available data; however, the USDA neither guarantees nor warrants the standard of the product, and the use of the name by USDA implies no approval of the product to the exclusion of others that may also be suitable.

Accepted for publication 9 December 2004

\section{Introduction}

With current technology, uterine capacity (UC) represents the major limit to litter size in swine (for review see Vallet 2000). Selection for UC using the unilaterally hysterectomized-ovariectomized (UHO) surgical model (Christenson et al. 1987) increased UC by approximately one live foetus per uterine horn (Christenson \& Leymaster 2002) compared with a randomly selected control line. Thus, alleles associated with increased UC should be in greater frequency in the UC selected line. In addition, previous reports from our laboratory have suggested that foetal erythropoiesis may influence UC (Pearson et al. 1998; Vallet et al. 2002, 2003). 
The erythropoietin receptor (EPOR) controls the terminal differentiation of foetal red blood cells (Moritz et al. 1997). Thus, the EPOR gene is a good candidate gene for association with UC. The objective of the current study was to determine whether DNA sequence variation in the EPOR gene is associated with UC in swine.

\section{Materials and methods}

\section{SNP discovery and genotyping assay}

Genomic DNAs were isolated from 44 pigs from various populations, including one pig from a line selected for ovulation rate $(\mathrm{OR})$, one pig from a control line, 21 pigs from a population of half Meishan, half white crossbred gilts, 20 pigs from a Yorkshire, Landrace, Duroc crossbred population and one pig from a Yorkshire, Landrace crossbred population. DNA was isolated from either tail tissue collected at birth or semen samples using a salt extraction method (Kappes et al. 2000). A primer pair was developed to amplify a region of the porcine EPOR gene predicted to encompass parts of exons 3, 4 and 5 and introns 3 and 4 (Table 1) by comparison with the human EPOR gene (GenBank accession number AJI011295). The region was amplified using the following thermocycling conditions: $95{ }^{\circ} \mathrm{C}$ for $30 \mathrm{~s}$ followed by 35 cycles of $95^{\circ} \mathrm{C}$ for $15 \mathrm{~s}, 58^{\circ} \mathrm{C}$ for $1 \mathrm{~min}, 72{ }^{\circ} \mathrm{C}$ for $2 \mathrm{~min}$. An approximately $1000 \mathrm{bp}$ product for each sample was isolated by gel purification using GENECLEAN (Qbiogene, Carlsbad, CA, USA) according to the instructions provided with the kit. The EPOR gene fragments were sequenced in each direction using cycle sequencing with the two EPOR-specific primers (Table 1). The resulting sequences were aligned using VECTOR NTI software (Informax, Frederick, MD, USA) and were examined for polymorphisms. A single nucleotide polymorphism (SNP) that appeared to occur at a very low frequency was observed in putative intron 4. A genotyping assay for this polymorphism was constructed using primer extension

Table 1 Primers used to clone, sequence and genotype regions of the porcine erythropoietin receptor (EPOR) gene.

\begin{tabular}{ll}
\hline Primer function & Primer sequence \\
\hline Forward - SNP discovery & CATGGCCACCTGCATCAAG \\
Reverse - SNP discovery & TGCTCAGCACGCACTCAG \\
Forward - genotyping assay & CTACCTGGGTCCCGTTCTG \\
Reverse - genotyping assay & agcggataacaatttcacacagg \\
& ATGGACCAAGCCAATCAGAG ${ }^{1}$ \\
Probe primer - & CCTCCTGCTTTCATTGCCT \\
genotyping assay & \\
\hline
\end{tabular}

${ }^{1}$ Lower case letters indicate that portion of the primer sequence that matches the biotinylated universal primer used for sequenom genotyping assays. Upper case letters are that portion of the primer sequence that is $E P O R$ gene specific.

SNP, single nucleotide polymorphism. and mass spectrometry (Sequenom, San Diego, CA, USA; Table 1).

\section{Collection of phenotypic data in unilaterally hysterectomized-ovariectomized gilts}

Collection of the phenotypic data from the UHO gilts used in this experiment was described by Christenson \& Leymaster (2002). Data were collected during four farrowing seasons. Briefly, 402 gilts (144 from the control line, 146 from the OR line and 112 from the UC line) were UHO at 160 days of age, and then mated at approximately 250 days of age. These gilts were progeny from the crossing of two separate replicates of the selection experiment, which was done to relieve inbreeding. Thus, for the most part, gilts were unrelated to each other. Gilts were slaughtered at 105 days of gestation, the remaining uterine horn was recovered, opened, and a blood sample was obtained from each living foetus. Then, each foetus and placenta was removed and weighed. In addition, the numbers of living and dead foetuses (mummies) were recorded for each litter. Spleens were collected from each foetus. Finally, the ovary was dissected to count the number of corpora lutea (CL). Foetal blood samples were used to determine haematocrit and foetal plasma iron concentrations as previously described (Vallet et al. 2002). DNA was isolated from tail tissue of each gilt using the salt extraction method. The genotype of each gilt was then determined using the EPOR SNP genotyping assay described above. DNA was also isolated using Wizard (Promega, Madison, WI, USA) kits from the spleen tissue of all foetuses of gilts that were determined to be heterozygous for the EPOR SNP and the DNA was used to determine the genotypes of each foetus in the litters. In addition, DNA from the boars that produced the litters was isolated from tail tissue using Wizard kits and these were used to genotype the boars to confirm that the boars were homozygous for the $C$ allele.

\section{Collection of phenotypic data in intact gilts}

Phenotypic information was also collected from 131 intact gilts from the OR line, as described in Christenson \& Leymaster (2002). Briefly, OR gilts were bred at 250 days of age and farrowed. At farrowing, the number of fully formed piglets born and the number of piglets born alive were recorded. DNA was isolated from tail tissue from these gilts using the salt extraction method and used to determine the EPOR genotype of each gilt.

Finally, the association between the presence of the SNP and litter size in a population of 622 gilts unrelated to the Meat Animal Research Center (MARC) selection lines was explored. This population was constructed by crossing white crossbred (Yorkshire-maternal Landrace) gilts with terminal sire Landrace or Duroc boars from several external sources (12 sire lines per breed), and then inter se mating 
the progeny. The total number born and the number born alive were recorded for all gilts in this population over eight farrowing seasons. DNA from blood from the original white crossbred gilts and semen from the original terminal sire boars was obtained using the salt extraction method. DNA from all female progeny for which litter size data were available, and for the sires of these matings, was obtained from tail tissue collected at birth using Wizard kits. The DNA was genotyped using the EPOR SNP genotyping assay described above.

\section{Statistical analysis}

For the data from UHO gilts, foetal haematocrit, foetal plasma iron, and foetal and placental weights were averaged within each litter. Litter size (a measure of UC), number of CL, within litter average foetal weight, placental weight, foetal haematocrit and foetal plasma iron concentrations were analysed using the PROC MIXED procedure of SAS. The model included effects of the maternal EPOR SNP genotypes, selection line (control, OR, UC), season, and the line by season interaction as fixed effects. Foetal sire was included in the model as a random effect.

Effects of foetal EPOR SNP genotypes on individual foetal haematocrits, foetal plasma iron concentrations, foetal weights and placental weights were analysed using PROC MIXED with a model that included the effects of line, season, line by season and foetal EPOR SNP genotypes. Gilt within line by season was included in the model as a random effect.

Effects of maternal EPOR SNP genotypes on numbers of fully formed and live piglets born to intact OR gilts were analysed using PROC MIXED and a model that included the effects of farrowing season and maternal EPOR genotypes as fixed effects, and foetal sire as a random effect.
Effects of EPOR SNP genotypes on the numbers of fully formed and live piglets born to the Yorkshire, Duroc, Landrace crossbred line gilts were analysed using PROC MIXED. For these data, genotypes of both the sire and the dam of the litter were known. This allowed an analysis to distinguish between the effects of the maternal and piglet EPOR SNP genotypes by fitting both factors simultaneously. The actual piglet genotypes were not known. However, the predicted frequency of the $T$ allele in the piglets of each litter $(0,0.25$, $0.5,0.75$ and 1) could be calculated based on the boar and gilt genotypes. Data were then analysed using a model that included farrowing season, the effects of the maternal EPOR SNP genotype, the linear effect of the predicted frequency of the $T$ allele in the piglets of the litter, and the interaction of the maternal EPOR SNP genotypes and the linear effect of the predicted piglet $T$ allele frequency. The boar used to produce each litter was included in the analysis as a random effect. Simultaneously fitting the maternal genotype and piglet genotype effects allowed an estimate of each effect adjusted for the other.

\section{Results}

\section{SNP discovery}

Only a single, low frequency $\mathrm{C} / \mathrm{T}$ SNP was detected within the region of the EPOR gene that was sequenced. The sequence surrounding and including this polymorphism was examined using signal scan to locate potential transcription or enhancer consensus sequences within this sequence, and the results of this analysis are presented in Fig. 1. The SNP T allele created a new GATA-1-binding site within intron 4 . In addition, other binding sites for Sp1, CCACC-binding protein (CBP) and GATA-1 were also found within the intron. Because of its potential effect on transcription of the EPOR gene, this polymorphism was chosen for further study.

\begin{tabular}{|c|c|c|}
\hline & 1 & $\begin{array}{c}\text { SP1 GATA-1 } \\
\text { GTGAGGCCCGCCCCTATCTCCTAGCCCCAAGGGCTGCACAGTCAATAGCA }\end{array}$ \\
\hline & $\perp$ & CBP CBP \\
\hline & 51 & $\begin{array}{l}\text { CCCACCTCTAAGTCCCACCCAGACGGTCACTATGGCCTCGCCCTCCACAT } \\
\text { SP1 }\end{array}$ \\
\hline & 101 & $\begin{array}{l}\text { TCCGCCCAAGACAGTTCCACATCTACCAACTTGTTCTCTTTCCTAATTTC } \\
\text { CBP CBP }\end{array}$ \\
\hline $\begin{array}{l}\text { Figure } 1 \text { The nucleotide sequence of the } \\
\text { region of intron } 4 \text { of the erythropoietin }\end{array}$ & 151 & $\begin{array}{c}\text { CССTTTCCCACCCCACCTGGACGCAATCCCAACTACCCCCTTGTCCCAAA } \\
\text { CBP }\end{array}$ \\
\hline $\begin{array}{l}\text { receptor }(E P O R) \text { gene surrounding the single } \\
\text { nucleotide polymorphism (SNP) is illustrated. }\end{array}$ & 201 & $\begin{array}{l}\text { CCCTAGGCCTCCTCAGGGTGGGGTCCTTTCACTGCGCTGGCCAGTCTGTT } \\
\text { SP1 }\end{array}$ \\
\hline $\begin{array}{l}\text { The } C / T \text { polymorphism is indicated in the box, } \\
\text { which also surrounds the GATA- } 1 \text { site com- }\end{array}$ & 251 & $\begin{array}{c}\text { AAATAGCCCAAGTCCGCCCTCTGCTACCTGGGTCCCGTTCTGATTGGTCC } \\
\text { GATA-1 }\end{array}$ \\
\hline $\begin{array}{l}\text { pleted by the } T \text { allele. Sp1 (Chin et al. 1995), } \\
\text { CCACC-binding protein (CBP; Youssoufian }\end{array}$ & 301 & CAGCTTTCCCAGGCCCCGCCTCCTGCTTTCATTGCCTAYCTCCCCAAGAG \\
\hline 1994) and GATA-1 (Chiba et al. 1991) refer to & & 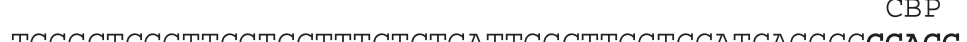 \\
\hline transcription factor-binding sites known to & 351 & TGGGCTCGGTTCGTCCTTTCTCTGATTGGCTTGGTCCATCAGGCCCCACC \\
\hline $\begin{array}{l}\text { influence } E P O R \text { gene transcription in other } \\
\text { species. }\end{array}$ & 401 & $\begin{array}{c}\mathrm{SP1} \\
\text { CCCAACATGCCСTTATTGGCCCGCCC }\end{array}$ \\
\hline
\end{tabular}




\section{UHO gilts}

Results from the UHO gilts from the three selected lines are summarized in Table 2. No gilts homozygous for the EPOR T allele were observed. The frequency of the $T$ allele was 2.8 and $3.1 \%$, which did not differ, and $7.6 \%(P<0.05)$ for control, OR, and UC line gilts, respectively, suggesting that a homozygous TT gilt would be expected at the rate of around one in 500 gilts. Because of the low $T$ allele frequency in these lines, data from all three lines were combined. Uterine capacity $(P<0.05)$ and average litter foetal plasma iron $(P<0.05)$ differed significantly between $C C$ and $C T$ gilts. No differences between EPOR SNP genotypes were observed in the other traits.

Table 2 Least-square mean values for uterine capacity, number of corpora lutea, and within litter average foetal haematocrit, foetal plasma iron, and foetal and placental weight from unilaterally hysterectomized-ovariectomized gilts from the control, OR and UC selected lines for each of the EPOR genotypes observed.

\begin{tabular}{lll}
\hline & \multicolumn{2}{l}{ Maternal genotype } \\
\cline { 2 - 3 } Trait & $C C$ & $C T$ \\
\hline Number of gilts & 368 & 34 \\
Number of control gilts & 136 & 8 \\
Number of OR gilts & 137 & 9 \\
Number of UC gilts & 95 & 17 \\
Uterine capacity & $7.3 \pm 0.2$ & $8.1 \pm 0.4^{1}$ \\
Number of corpus luteum & $14.7 \pm 0.2$ & $14.9 \pm 0.5$ \\
Average foetal haematocrit & $36.9 \pm 0.2$ & $37.1 \pm 0.5$ \\
Average foetal plasma iron & $0.59 \pm 0.02$ & $0.48 \pm 0.05^{2}$ \\
Average foetal weight & $793 \pm 13$ & $769 \pm 28$ \\
Average placental weight & $190 \pm 4$ & $176 \pm 9$ \\
\hline
\end{tabular}

$E P O R$, erythropoietin receptor; $\mathrm{OR}$, ovulation rate; UC, uterine capacity; SNP, single nucleotide polymorphism.

${ }^{1}$ Gilts heterozygous for the EPOR SNP differed from gilts that were $C C$ for the SNP $(P<0.05)$.

${ }^{2} E P O R$ heterozygous gilts different from $E P O R$ homozygous gilts $(P=$ 0.05).

Table 3 Least-square mean values for traits measured on individual foetuses with $C C$ or $C T$ genotypes from litters in which the gilt was $C T$ and the boar was CC for the EPOR SNP.

\begin{tabular}{lcr}
\hline & \multicolumn{2}{l}{ Foetal genotype } \\
\cline { 2 - 3 } Trait & \multicolumn{1}{c}{$C C^{1}$} & \multicolumn{1}{c}{$C T$} \\
\hline Average number of foetuses per litter & $3.6 \pm 0.3$ & $3.8 \pm 0.3$ \\
Foetal haematocrit $(\%)$ & $37.4 \pm 0.8$ & $37.1 \pm 0.7$ \\
Foetal plasma iron $(\mu \mathrm{g} / \mathrm{ml})$ & $1.2 \pm 0.1$ & $1.2 \pm 0.1$ \\
Foetal weight $(\mathrm{g})$ & $759 \pm 37$ & $769 \pm 36$ \\
Placental weight $(\mathrm{g})$ & $167 \pm 12$ & $174 \pm 11$ \\
Number of foetuses & 111 & \multicolumn{1}{c}{133} \\
\hline
\end{tabular}

Two of the $C T$ gilts from the selected lines were mated to $C T$ boars, and foetal data from these matings were excluded.

${ }^{1}$ Differences between genotypes were not significant.

$E P O R$, erythropoietin receptor; SNP, single nucleotide polymorphism.
Table 4 Least-square mean values for number of fully formed piglets and the number of live piglets born to intact gilts from the OR line differing in $E P O R$ genotypes.

\begin{tabular}{lll}
\hline & \multicolumn{2}{l}{ Maternal genotype } \\
\cline { 2 - 3 } Trait & $C C$ & $C T$ \\
\hline Number of gilts & 124 & 7 \\
Number of fully formed piglets born & $10.8 \pm 0.3$ & $13.6 \pm 1.1^{1}$ \\
Number of live piglets born & $10.1 \pm 0.3$ & $12.8 \pm 1.1^{1}$ \\
\hline
\end{tabular}

$E P O R$, erythropoietin receptor; $\mathrm{OR}$, ovulation rate; SNP, single nucleotide polymorphism.

${ }^{1}$ Gilts heterozygous for the EPOR SNP were different from homozygous gilts $(P<0.05)$.

Results from individual foetuses within litters of gilts that were heterozygous, and for which the boar was homozygous $C$ for the EPOR SNP, are presented in Table 3. No significant effects of EPOR SNP genotype were detected on any of the traits measured.

\section{Intact gilts}

Results from the intact OR gilts (Table 4) were similar to the results of the UHO gilts in that gilts that were heterozygous at the EPOR locus had a greater number of fully formed and born alive piglets at farrowing $(P<0.05)$ compared with homozygous $C C$ gilts. However, because of the low frequency $(2.7 \%)$ of the $T$ allele in this population of gilts, only seven gilts were heterozygous for the EPOR SNP.

The association between the EPOR SNP and litter size was also examined in a population of Yorkshire, Landrace and Duroc crossbred pigs that was unrelated to the MARC selected lines. For both the total piglets born and the number of piglets born alive, neither the interaction between the maternal and foetal genotypes, nor the effect of the maternal EPOR SNP genotype was significant. The effect of the predicted foetal EPOR T allele frequency on the total number of piglets born approached but did not reach statistical significance $(P=0.07$; Fig. 2$)$. In contrast, the effect of the foetal EPOR $T$ allele frequency on the number of piglets born alive was statistically significant $(P<0.01)$. The prediction equation for the linear effect of the foetal $T$ allele frequency predicted that litters in which all foetuses were homozygous for the $T$ allele would have $2.6 \pm 1.0$ more piglets born alive than litters in which all foetuses were homozygous for the $C$ allele (Fig. 2), although no litters predicted to be homozygous for the $T$ allele were observed. Thus, these data suggest a significant association between the EPOR genotype of the foetus and litter size.

\section{Discussion}

This is the first report of a polymorphism in a defined gene that is associated specifically with UC, although others have 


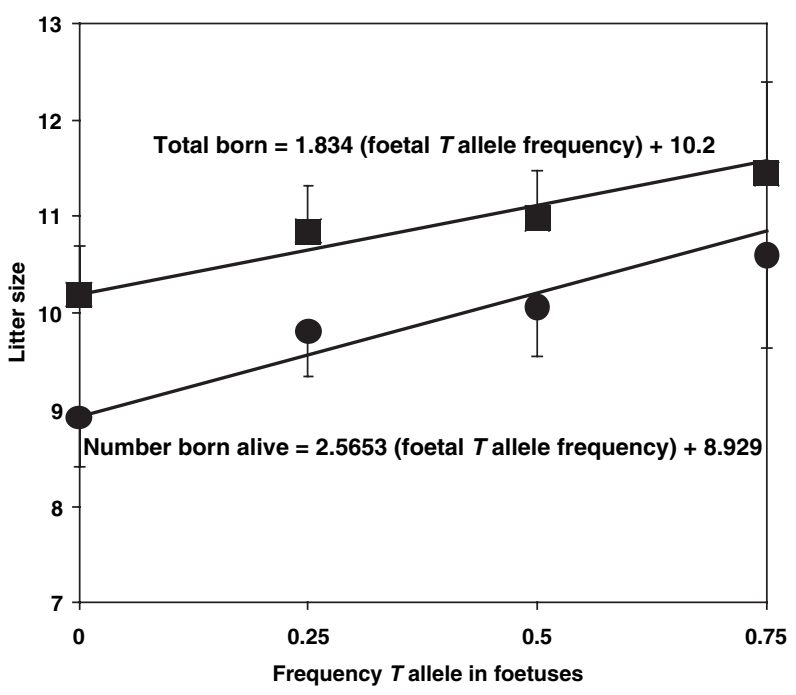

Figure 2 The least-square mean values for total fully formed piglets born (squares) and number piglets born alive (circles) are illustrated for the different foetal $T$ allele frequencies predicted based on the sow and boar genotypes for each litter. The dashed and solid lines indicate the linear relationships between the predicted foetal $T$ allele frequency and total piglets born and piglets born alive, respectively. The relationship between predicted foetal $T$ allele frequency and piglets born alive was significant $(P<0.01)$. Number of observations were 289, 266, 55 and 12 for frequencies of $0,0.25,0.5$ and 0.75 , respectively.

shown associations between quantitative trait loci (QTL) regions and UC (Rohrer et al. 1999) or between defined genes and litter size (see below). The association between the EPOR SNP and difference in litter size was also found in intact gilts from the OR selected line and the Yorkshire, Landrace, Duroc crossbred line, which is consistent with the concept that UC is a component trait of overall litter size (Christenson et al. 1987). Although the EPOR gene was initially chosen based on a predicted influence on foetal erythropoiesis, no associations between foetal haematocrits and EPOR SNP genotype were detected. Nonetheless, the effect of the EPOR SNP is most likely mediated by effects in the foetus, and the magnitude of the increase in litter size was estimated to be two to three piglets born alive per litter. Thus, genetic variation in the EPOR gene influences UC, and could be exploited to improve litter size in swine.

There have been several reports of chromosomal regions that affect litter size or UC. These investigations use two approaches: use of a genome scan or investigation of candidate genes. Using the genome scan approach, QTL for litter size have been observed on porcine chromosomes 6 (Wilkie et al. 1999), 8 (King et al. 2003) and 11 (Cassady et al. 2001). A QTL for UC has also been reported on chromosome 8 (Rohrer et al. 1999). The EPOR gene is located on chromosome 2 (Fahrenkrug et al. 2000). Thus, the location of this gene is different from QTL previously associated with litter size or UC.

The candidate gene approach has been used to demonstrate associations between specific genes and litter size.
Polymorphisms in the oestrogen receptor (Rothschild et al. 1996; Short et al. 1997), prolactin receptor (Rothschild et al. 1997; Van Rens \& Van der Lende 2002) and retinolbinding protein (Rothschild et al. 2000) genes have all been reported to be associated with litter size in pigs. However, others have investigated the association of these loci with litter size and obtained equivocal results (Van Rens et al. 2000, 2002, 2003; Drogemuller et al. 2001; Linville et al. 2001). Polymorphisms associated with a trait in one population of pigs may not be associated with that trait in other populations, due to recombination events, lack of similar segregating QTL nearby, sampling or other mechanisms. However, polymorphisms that alter gene function, either by changing the coding region of the protein, translation or stability of the mRNA or control of transcription of the gene would be expected to cause similar effects across different populations of pigs (barring effects of epistasis at other loci).

We have previously shown that the transcription of the EPOR gene increases dramatically in the foetal liver between day 24 and 40 of pregnancy (Pearson et al. 2000). During this period, foetal red blood cells change from mostly nucleated (immature) to mostly non-nucleated (adult type) red blood cells. Foetuses are also unusually susceptible to loss due to intrauterine crowding during this period (Knight et al. 1977; Vallet 2000; Vonnahme et al. 2002). Intrauterine crowding is also associated with a decrease in foetal weight (Knight et al. 1977; Vallet \& Christenson 1993; Vallet et al. 2003) and foetal weight is positively correlated with foetal haematocrit (Pearson et al. 1998; Vallet et al. 2002). Thus, intrauterine crowding produces a subset of small foetuses within a litter with impaired foetal red blood cell development and this could contribute to the foetal losses. The EPOR binding to EPO is known to control the maturation and number of red blood cells (Moritz et al. 1997), and thus, is a candidate gene for associations with UC and litter size. Although differences in UC were detected, no effect of the EPOR SNP on foetal haematocrit on day 105 of pregnancy was observed. However, signal scan analysis of the region surrounding the SNP suggested that this region might affect transcription of the EPOR gene. Intron 4 has similarity to regions known to control both the transcription of the EPOR and $\beta$-globin genes, in that it contains binding sites for GATA-1, Sp1 and CBPs, three proteins involved in transcriptional control in erythroid cells (Chiba et al. 1991; Youssoufian 1994; Chin et al. 1995; Ohneda \& Yamamoto 2002). These transcription factors operate remotely to the gene being transcribed (Strauss \& Orkin 1992). The $T$ allele of the SNP introduces an extra GATA-1 site, and GATA-1 gene expression in mice peaks at the proerythroblast stage (Ohneda \& Yamamoto 2002). These primitive red blood cells are present in the circulation of pig foetuses before day 30 and disappear by day 40 of gestation (Pearson et al. 1998). Thus, an SNP that creates an extra GATA-1 site in the EPOR gene could be predicted to alter EPOR gene transcription, possibly accelerating foetal red 
blood cell maturation, and could easily be a functional polymorphism for this trait. This proposed effect would be similar to that observed in Meishan pigs (Pearson et al. 1998; Vallet et al. 2003), a breed reported to have greater embryonic survival and UC than European breeds (Haley \& Lee 1993). Further experiments to examine differences in foetal red blood cell maturation and foetal liver expression of EPOR during the period between day 25 and 40 of pregnancy are planned.

Uterine capacity and litter size are related traits that are influenced by genes that are expressed by both the gilt and the foetus. For a given gene polymorphism that is associated with either trait, it can be difficult to determine whether the association is with the maternal or the foetal genotype, because the two are confounded. In the experiments reported here, two opportunities to distinguish between maternal and foetal genotype effects were available. If the effect of the EPOR SNP on UC and litter size is based on the foetal genotype, then within the litters of $C T$ gilts mated to CC boars (Table 3), more CT foetuses should be present. Although a trend favouring $C T$ foetuses was present, the difference was not significant. By fitting both the maternal and foetal genotype effects simultaneously, the independent portions of the maternal and foetal genotype effect was estimated in the Yorkshire, Landrace, Duroc crossbred population. When this was done, the maternal genotype effect, adjusted for the foetal genotype effect, was not significant. By contrast, the foetal genotype effect, adjusted for the maternal genotype effect, remained statistically significant. Thus, this analysis provides evidence that the association between the EPOR SNP and litter size is primarily a foetal genotype effect, and is consistent with the hypothesis that the EPOR SNP may affect foetal erythropoiesis. The absence of any effect of the EPOR SNP on foetal haematocrit at day 105 of gestation is most likely explained by the fact that samples for analysis of foetal haematocrit were collected during late pregnancy, when the effect of the genotype may not be observable. Nevertheless, because the effect appears to be foetal, the results indicate that selection of boars for the EPOR SNP should be an effective strategy to modify litter size.

Finally, an SNP associated with foetal survival, such as that presented here, would be expected to increase in frequency over time, as foetuses possessing the beneficial allele would be favoured. Yet, in both the selected lines and the BX line, the frequency of the favourable $T$ allele was relatively low, although selection for UC did significantly increase $T$ allele frequency in the UC line compared with the control line. Two explanations seem likely. First, because the $T$ allele is associated with UC, the effect of the genotype on survival would only be expected to occur in gilts with ORs that exceed UC. Secondly, UC itself is likely to be a multigenic trait. Polymorphisms in numerous genes affecting uterine, placental or foetal functions likely influence this complex trait. Selection pressure on any single polymorphism in a particular gene would likely be small against such a background of competing genetic variation. Individual genetic markers would be expected to be most useful given this potential scenario. However, because litter size requires both high OR and high UC, this SNP is only likely to be useful in gilts in which OR exceeds UC.

\section{References}

Cassady J.P., Johnson R.K., Pomp D., Rohrer G.A., Van Vleck L.D., Spiegel E.K. \& Gilson K.M. (2001) Identification of quantitative trait loci affecting reproduction in pigs. Journal of Animal Science 79, 623-33.

Chiba T., Ikawa Y. \& Todokoro K. (1991) GATA-1 transactivates erythropoietin receptor gene, and erythropoietin receptor-mediated signals enhance GATA-1 gene expression. Nucleic Acids Research 19, 3843-8.

Chin K., Oda N., Shen K. \& Noguchi C.T. (1995) Regulation of transcription of the human erythropoietin receptor gene by proteins binding to GATA-1 and Sp1 motifs. Nucleic Acids Research 23, 3041-9.

Christenson R.K. \& Leymaster K.A. (2002) Correlated responses in gravid uterine, farrowing and weaning traits to selection of pigs for ovulation rate or uterine capacity. In: Proceedings of 7 th World Congress on Genetics Applied to Livestock Production (Communication No. 08-25), 19-23 August 2002, Montpelier, France.

Christenson R.K., Leymaster K.A. \& Young L.D. (1987) Justification of unilateral hysterectomy-ovariectomy as a model to evaluate uterine capacity in swine. Journal of Animal Science 65, 738-44.

Drogemuller C., Hamann H. \& Distl O. (2001) Candidate gene markers for litter size in different German lines. Journal of Animal Science 79, 2565-70.

Fahrenkrug S.C., Campbell E.M., Vallet J.L. \& Rohrer G.A. (2000) Physical assignment of the porcine erythropoietin receptor gene to SSC2. Animal Genetics 31, 69-70.

Haley C.S. \& Lee G.J. (1993) Genetic basis of prolificacy in Meishan pigs. Journal of Reproduction and Fertility Supplement 48, 247-59.

Kappes S.M., Bennett G.L., Keele J.W., Echternkamp S.E., Gregory K.E. \& Thalman R.M. (2000) Initial results of genomic scans for ovulation rate in a cattle population selected for increased twinning rate. Journal of Animal Science 78, 3053-9.

King A.H., Jiang Z., Gibson J.P., Haley C.S. \& Archibald A.L. (2003) Mapping quantitative trait loci affecting female reproductive traits on porcine chromosome 8. Biology of Reproduction 68, 2172-9.

Knight J.W., Bazer F.W., Thatcher W.W., Franke D.E. \& Wallace H.D. (1977) Conceptus development in intact and unilaterally hysterectomized-ovariectomized gilts: Interrelationships among hormonal status, placental development, fetal fluids, and fetal growth. Journal of Animal Science 44, 620-37.

Linville R.C., Pomp D., Johnson R.K. \& Rothschild M.F. (2001) Candidate gene analysis for loci affecting litter size and ovulation rate in swine. Journal of Animal Science 79, 60-7.

Moritz K.M., Lim G.B. \& Wintour E.M. (1997) Developmental regulation of erythropoietin and erythropoiesis. American Journal of Physiology 273, R1829-44.

Ohneda K. \& Yamamoto M. (2002) Roles of hematopoietic transcription factors GATA-1 and GATA-2 in the development of red blood cell lineage. Acta Haematologica 108, 237-45. 
Pearson P.L., Klemcke H.G., Christenson R.K. \& Vallet J.L. (1998) Uterine environment and breed effects on erythropoiesis and liver protein secretion in late embryonic and early fetal swine. Biology of Reproduction 58, 911-8.

Pearson P.L., Smith T.P.L., Sonstegardt T.S., Klemcke H.G., Christenson R.K. \& Vallet J.L. (2000) Porcine erythropoietin receptor: molecular cloning and expression in embryonic and fetal liver. Domestic Animal Endocrinology 19, 25-38.

Rohrer G.A., Ford J.J., Wise T.H., Vallet J.L. \& Christenson R.K. (1999) Identification of quantitative trait loci affecting female reproductive traits in a multigeneration Meishan-White composite swine population. Journal of Animal Science 77, 1385-91.

Rothschild M., Jacobsen C., Vaske D. et al. (1996) The estrogen receptor locus is associated with a major gene influencing litter size in pigs. Proceedings of the National Academy of Sciences of the United States of America 93, 201-5.

Rothschild M.F., Messer L.A. \& Vincent A. (1997) Molecular approaches to improved pig fertility. Journal of Reproduction and Fertility Supplement 52, 227-36.

Rothschild M.F., Messer L., Day A., Wales R., Short T., Southwood O. \& Plastow G. (2000) Investigation of the retinol-binding protein 4 (RBP4) gene as a candidate gene for increased litter size in pigs. Mammalian Genome 11, 75-7.

Short T.H., Rothschild M.F., Southwood O.I. et al. (1997) Effect of the estrogen receptor locus on reproduction and production traits in four commercial pig lines. Journal of Animal Science 75, 3138 42 .

Strauss E.C. \& Orkin S.H. (1992) In vivo protein-DNA interactions at hypersensitive site 3 of the human $\beta$-globin locus control region. Proceedings of the National Academy of Sciences of the United States of America 89, 5809-13.

Vallet J.L. (2000) Fetal erythropoiesis and other factors which influence uterine capacity in swine. Journal of Applied Animal Research 17, 1-26.
Vallet J.L. \& Christenson R.K. (1993) Uterine space affects placental protein secretion in swine. Biology of Reproduction 48, 575-84.

Vallet J.L., Klemcke H.G. \& Christenson R.K. (2002) Interrelationships among conceptus size, uterine protein secretion, fetal erythropoiesis, and uterine capacity. Journal of Animal Science 80, 729-37.

Vallet J.L., Klemcke H.G., Christenson R.K. \& Pearson P.L. (2003) The effect of breed and intrauterine crowding on fetal erythropoiesis on day 35 of gestation in swine. Journal of Animal Science 81, 2352-6.

Van Rens B.T.T.M. \& Van der Lende T. (2002) Litter size and piglet traits of gilts with different prolactin receptor genotypes. Theriogenology 57, 883-93.

Van Rens B.T.T.M., Hazeleger W. \& Van der Lende T. (2000) Periovulatory hormone profiles and components of litter size in gilts with different estrogen receptor (ESR) genotypes. Theriogenology 53, 1375-87.

Van Rens B.T.T.M., De Groot P.N. \& Van der Lende T. (2002) The effect of estrogen receptor genotype on litter size and placental traits at term in F2 crossbred gilts. Theriogenology 57, 1635-49.

Van Rens B.T.T.M., Evans G.J. \& Van der Lende T. (2003) Components of litter size in gilts with different prolactin receptor genotypes. Theriogenology 59, 915-26.

Vonnahme K.A., Wilson M.E., Foxcroft G.R. \& Ford S.P. (2002) Impacts on conceptus survival in a commercial swine herd. Journal of Animal Science 80, 553-9.

Wilkie P.J., Paszek A.A., Beattie C.W., Alexander L.J., Wheeler M.B. \& Schook L.B. (1999) A genomic scan of porcine reproductive traits reveals possible quantitative trait loci (QTLs) for number of corpora lutea. Mammalian Genome 10, 573-8.

Youssoufian H. (1994) Further characterization of cis-acting regulatory sequences in the genomic locus of the murine erythropoietin receptor: evidence for stage-specific regulation. Blood 83, 1428-35. 